Lord Brain's book is said to be intended for a nonspecialist audience. The general concept of the book is good, but in many places precision is lost by undue compression or elision. In a few places technical terms are introduced without any explanation (for example, "geniculate cell"). The first essay, "Science and Behaviour", is not novel except perhaps in its scope. An attempt is made to extend by analogy to social systems, but it is not made clear whether control could be by individuals, by a hierarchical organization, or by Wellsian "world brains". "Perception, a Trialogue" is a slightly precious attempt to review biological, psychological and philosophical ideas about perception. It does not achieve the clarity its arguments deserve, but some of them aro restated in the next essay, "The Status of Mind"; a dualist approach is adopted despite apt comment on Whitehead's concept of "prehension". This essay finishes with a long quotation which seems not only obscure in itself but also unrelated to previous argument. His final essay, "Science and Antiscience", is by far the best; it has authority, and includes a very good discussion of the mind-body problem as related to the parts-whole concept.

Bronowski's book is more personal. It is a development of his "Science and Human Values" and has lucidity, together with a charming simplicity" which only very rarely may mislead the uninformed reader. Each essay is formed of small chapters, and each chapter is an elegant exposition of a thought. He begins with discussion of the fear that mechanical interpretation of man's nature has been eroding more and more from our personal image, and asserts that there is a core the nature of which is different in the special sense that a machine could not be programmed to exhibit its properties. But later he deals with this "self" and shows it as an integral part of man's nature; here he uses particularly apt phrases and finds literary quotes very much to his purpose.

Science and Man is a more scholarly work than the other. It quotes references (usually books, but often original papers) and is concerned to instruct the reader. There is a flavour of adult education, and the author's explicit attempt to instruct politicians in the ways of science is not subtle.

Bronowski, on the other hand, is conducting an informal seminar; his conclusions, especially those about the ethic which derives from scientific endeavour, would be arrived at by a student in such a seminar. They are a littlo solfconsciously noble, but are nevertheless valuable, and Lord Brain's politicians would be edified as well as instructed. Lord Brain's book would do a service on the shelf of any public library, but Bronowski should become recommended reading for all students. JACK CoHen

\section{DATING FOSSIL MAN}

\section{Frameworks for Dating Fossil Man}

By Kenneth P. Oakley. Second edition. Pp. $\mathrm{x}+355$. (London: Weidenfeld and Nicolson, 1966.) 45s. not.

IT is a measure of the importance that this book has assumed that a new edition should have been considered necessary less than two years after the first. At first glanco it seems very little different from the originaleven the pagination remains the same. The text itself, apart from the addition of a few qualifying clauses, remains virtually unaltered except for more detailed reference to the Buda hearths at Vérteszöllös, based on the 1965 paper of Kretzoi and Vértes. The recent recognition of the skull of Homo sapiens at Vérteszöllös, however, which pushes the carliest record of this type right back to a Mindel interstadial, came too late to be discussed in this edition. The typographical errors in the first edition have mostly, though not all, been corrected, and adjustments have also been made to three of the figures. Two others (Figs. 43 and 65) have been re-drawn. The list of references to Part 1 remains the same, but some halfdozen have been added to Part 2, without comment in the text.

The really important revisions have been made in the sixteen Dating Tables at the end of the book. The first table (Australopithecines) has several adjustments to names, stratigraphy and dating, and in both this and Table II (Pithecanthropines) a record is deleted. Tables III, IV, V, VI and VII (Neanderthaloids and Neanderthalers of Europe, U.S.S.R., Near East, Far East and North Africa) are practically unaltered, but Table VIII (Homo sapiens Neanderthaloids, etc., in Africa south of the Sahara) shows some considerable increases of A3 dates. The long Table IX (Upper Palacolithic of Europe) is virtually unchanged apart from the inclusion of the Cro-Magnon type recently found at Sungir, U.S.S.R.; Table $\mathrm{X}$ is also the same as before. There has been some? revision of stratigraphy in Table XI (Later Stone Age of North Africa), and some new dates are added, but it is not obvious why the Ishango site on the eastern border of the Congo has been added here rather than to Table XII (Later Stone Age in Africa south of the Sahara). Table XII now includes the Oakwood and Mumbwa sites, neither of them new discoveries, as well as several now dates to sites already included. Many new dates are also given in Tables XIII (Mesolithic of Europe) and XIV (Mesolithic of Asia and Australasia), but the last two tables. XV (American Palaeoindian) and XVI (Hominid remains of dubious or revised antiquity), remain unaltered. Most of the amendments in these tables are given without disenssion or reference to the literature, so one is left guessing whether they are old or new work. Nevertheless, the value of this unique collection of records has been greatly enhanced.

Externally the new edition is identical in appearance to the old, so that confusion on library shelves is inevit able; the words "second edition" on the spine would have been helpful. Happily the publishers have kept the price identical as well.

G. W. Dimbleby

\section{THYROID METABOLISM}

\section{Current Topics in Thyroid Research}

Edited by C. Cassano and M. Andreoli. (Proceedings of the Fifth International Thyroid Conference, Rome, 1965.) Pp. xxvii + 1219. (Now York: Acadernic Press, Ine.; London: Academic Press, Inc. (London), Ltd., 1965.) n.p.

THE past decade has seen some striking advancess in our knowledge of thyroid function and of thyroicl pathology. The study of thyroid metabolism is, of course. enormously assisted by the fact that iodine is an essential constituent of thyroxine and of tri-iodothyronine, and the availability of radioactive isotopes of iodine has been an essential factor in onlarging this section of knowledge. A second crucial line of development was initiated by the independent observations of Roitt, Doniach, Campbell and Hudson in Britain, and of Rose and Witebsky in the United States, that circulating antibody to thyroid antigen was intimately associated with at discase of the thyroid described by Hashimoto, in which the thyroid gland is enlarged by infiltration with lymphocytes and related cells, and in which there is a good deal of fibrous tissute. A third point of development, as yet not so fully worked out, was the discovery by Adams and Purves that patients with Graves disease had a substance in their plasma which caused increased thyroid activity, but which was different from the thyroid stimulating hormone dorived from the anterior pituitary. A fourth sphere lies in the study of the way in which thyroxine and tri-iodothyronine are carried in the circulation largely bound to protein, and of the implications which this may have on the release of hormone from the thyroid and the supply of hormone to the 